\title{
EFEKTIVITAS PEMBENTUKAN KARAKTER SPIRITUAL UNTUK MENINGKATKAN OPTIMISME TERHADAP MASA DEPAN ANAK YATIM PIATU
}

\section{THE EFFECT OF SPIRITUAL CHARACTER BUILDING TO ENHANCE THE OPTIMISM TOWARD THE FUTURE AMONG ORPHAN CHILD}

\author{
Miftahun Ni'mah Suseno \\ Program Studi Psikologi Fakultas Ilmu Sosial dan Humaniora \\ Universitas Islam Negeri Sunan Kalijaga Yogyakarta \\ Email:miftahsuseno@uinsuka.ac.id
}

\begin{abstract}
This research examined the effect of spiritual character building toenhance optimism toward future among orphan child. The subjects of this experiment were 14 orphan children with age ranging from 12-17 years old. The design of this experiment was Pre-test-Post-test with Control Group Design. The result show that there is a difference in optimism toward future between experimental and control group $(t=1,000$; $p<0.01$ ). This means that the spiritual character building training show influence in increasing optimism toward future. An experiment group data analysis show that there is a difference in optimism toward future prior and after the training $(Z=-2,366 ; p<0.05)$, it is means that optimis toward future increasing after experiment. The result of this experiment confirmed the hypothesis.
\end{abstract}

Keyword: spiritual character building, optimism, orphan child

\begin{abstract}
ABSTRAK
Penelitian ini bertujuan untuk mengetahui efektivitas pembentukan karakter spiritual dalam meningkatkan optimisme terhadap masa depan pada anak yatim piatu. Subjek penelitian ini adalah 14 anak yang tinggal di panti asuhan berusia antara 12-17 tahun. Desain penelitian eksperimen ini menggunakan 2 kelompok penelitian, yaitu kelompok eksperimen dan kelompok kontrol dan dilakukan pengambilan data sebelum dan sesudah perlakuan. Hasil penelitian menunjukkan adanya perbedaan optimisme terhadap masa depan antara kelompok eksperimen dan kelompok kontrol $(t=1,000 ; p<0.01)$. Hal ini menunjukkan pembentukan karakater spiritual meningkatkan optimisme terhadap masa depan. Dari data kelompok eksperimen, diketahui adanya perbedaan optimisme terhadap masa depan sebelum dan sesudah perlakuan $(Z=-2,366 ; p<0.05)$, artinya optimisme terhadap masa depan meningkat setelah diberikan perlakuan. Hasil penelitian ini sesuai dengan hipotesis yang diajukan.
\end{abstract}

Kata kunci: pembentukan karakter spiritual, optimisme, anak yatim piatu 
Masa remaja merupakan masa yang paling menarik untuk dipelajari, karena banyak sekali masalah yang dihadapi. Seiring dengan perkembangan zaman dan peradaban, remaja menghadapi permasalahan yang semakin kompleks. Hampir semua remaja mengalami masa krisis, demikian juga yang dialami remaja yatim piatu.

Remaja adalah masa yang penuh dengan permasalahan. Statement ini sudah dikemukakan jauh pada masa lalu, yaitu di awal abad ke-20 oleh bapak psikologi remaja, yaitu Stanley Hall. Masa remaja merupakan masa yang ditandai oleh adanya badai dan tekanan (storm and stress) yang dimulai dengan adanya perubahan-perubahan biologis. Perubahan tersebut ditandai dengan adanya perubahan fisik yang membawa dampak pada keadaan emosional yang mudah tersinggung, bergejolak, dan mudah goyah.

Tekanan emosi pada remaja yang berstatus yatim piatu dapat menghambat perkembangan pribadinya dengan menampilkan sikap menutup diri, bertindak agresif, atau sebaliknya menampakkan kebimbangan dan keragu-raguan. Emosi anak yatim piatu selalu bergejolak di satu pihak karena kondisi dirinya yang berbeda dengan teman, orang lain dan di pihak lain karena pengaruh dari luar yang diterimanya. Permasalahan yang akan dihadapi oleh anak yatim antara lain adalah perasaan berbeda dengan orang lain, ada sesuatu yang kurang dengan dirinya, dan adanya perlakuan yang berbeda dari lingkungan. Kondisi ini dapat memicu terjadinya tekanan emosi pada anak yatim piatu.

Anak yatim piatu juga mengalami masa transisi seperti remaja normal lainnya. Gejolak jiwa yang tidak menentu dalam mencari identitas dirinya membuat mereka mengalami krisis yang lebih kompleks dibanding dengan remaja normal lainnya (Hurlock, 2000).

Hasil wawancara dengan lima remaja yang tinggal di Panti Asuhan Putri Aisyiyah Yogyakarta menunjukkan bahwa kekhawatiran terhadap masa depan merupakan hal yang selama ini sering muncul dalam pemikiran. Terkadang mereka membayangkan akan menghadapi situasi yang sulit di masa depan karena status mereka sebagai remaja yang tinggal di panti asuhan. Masa depan ini terkait dengan biaya pendidikan untuk melanjutkan studi, orientasi karir pekerjaan, status mereka di sosial masyarakat, dan masa depan membangun keluarga.

Efek yang dirasakan dari adanya kekhawatiran ini adalah terkadang merasa kurang percaya diri, kurang yakin dengan potensi yang dimiliki, pesimis untuk membangun cita-cita yang tinggi, merasa cukup menjalani apa yang ada 
saat ini dan tidak berani untuk berharap yang muluk-muluk, dalam interaksi sosial terkadang merasa minder dan muncul perasaan berbeda dengan orang lain.

Pola kehidupan di panti asuhan telah diupayakan untuk membentuk pribadi yang mandiri, percaya diri dan membangun kemampuan untuk bersosialisasi dengan masyarakat umum, namun pada kenyataannya perkembangan psikologis yang terjadi pada diri remaja yang tinggal di panti asuhan berbeda-beda. Ada yang merasa percaya diri dan mandiri dalam bersikap, namun ada juga remaja di panti yang masih membutuhkan dukungan untuk membentuk karakter pribadi yang tangguh, percaya diri, dan optimis terhadap masa depan.

Di tengah kondisi seperti itu, anak yatim piatu diharapkan memiliki sikap positif dari dalam dirinya untuk mampu bertahan dengan tetap memiliki harapanharapan yang baik akan masa depan, bahkan dengan kondisi yang dihadapinya. Individu yang memiliki pola pandang positif, memiliki harapan masa depan yang baik meskipun dengan banyak tantangan dan kemalangan dikenal dengan individu yang memiliki optimisme (Scheier \& Carver, dalam Snyder, 2002). Optimisme merupakan sikap selalu memiliki harapan baik dalam segala hal serta kecenderungan untuk mengharapkan hasil yang menye- nangkan. Dengan kata lain optimisme adalah cara berpikir atau paradigma berpikir positif (Carver \& Scheier 1993). Orang yang optimis adalah orang yang memiliki ekspektasi yang baik pada masa depan dalam kehidupannya. Masa depan mencakup tujuan dan harapan-harapan yang baik dan positif mencakup seluruh aspek kehidupannya (Scheier \& Carver, dalam Snyder, 2002)

Usaha menumbuhkan optimisme terhadap masa depan merupakan hal yang penting untuk dilakukan agar anak yatim piatu memiliki cara berpikir yang positif terhadap kondisi yang mereka alami dan mempunyai harapan terhadap masa depan dalam kehidupannya di masa depan. Salah satu alternatif intervensi yang dapat digunakan untuk meningkatkan optimisme adalah pembentukan karakter spiritual. Hal ini sesuai dengan hasil penelitian Coward dan Reed; Le dan Levenson; Levenson, Jennings, Aldwin, dan Shiraisi sebagaimana dirangkum oleh Zinnbauer dan Pargament (2005) yang menunjukkan bahwa spiritualitas berhubungan positif dengan kesehatan mental dan kebahagiaan hidup. Spiritualitas juga memiliki korelasi positif dengan kebahagiaan (Levin \& Chatters dalam Cohen, 2002); meningkatkan afek positif (Daaleman \& Frey, 2004); dan kepuasan hidup (Moreira-Almeida, Neto, \& Koenig, 2006). 
Spiritualitas membuat individu dewasa menjalani pengalaman hidupnya sebagai peristiwa yang penuh makna sekalipun ia menghadapi tantangan yang serius dan mengancam kepuasan hidupnya. Memaksimalkan spiritualitas akan mengembalikan fungsi manusia sebagai individu yang sehat dan memiliki kekuatan pribadi untuk bangkit ketika menghadapi situasi yang sulit.

Oleh karena itu penelitian ini memfokuskan pada pengembangan spiritualitas melalui Spiritual Character Building untuk meningkatkan optimisme terhadap masa depan pada anak yatim piatu. Pengembangan spiritualitas akan memberikan kekuatan dan keyakinan dalam diri anak yatim piatu untuk merasakan kehadiran Tuhan dalam kehidupannya sehingga akan memberikan perasaan optimis terhadap masa depan.

Sikap optimis disebut dengan optimisme. Optimisme adalah kepercayaan bahwa kejadian di masa depan akan memiliki hasil yang positif (Scheier, Carver, \& Bridges, 2001). Terdapat dua pandangan utama mengenai optimisme, "the explanatory style" dan "the dispositional optimism view," yang juga disebut sebagai "the direct belief view" (Caver \& Scheier, 2002):

\section{Explanatory Style}

Explanatory Style merupakan pandangan yang melihat bahwa kepercayaan seseorang ditentukan oleh pengalaman masa lampau. Pandangan ini didasarkan pada person's attributional style (Scheier, Carver, \& Bridges, 2000). Attributional style dibentuk oleh cara kita mempersepsikan, menjelaskan pengalaman masa lampau. Jika persepsi atau penjelasan yang dipegang adalah negatif, maka kita akan mengharapkan hasil yang negatif pada masa depan. Perasaan learned helplessness berlebihan dan kita percaya bahwa kita tidak dapat mengubah pandangan kita terhadap dunia. Attributional style secara khusus diukur dengan dengan menggunakan Attributional Style Questionnaire (ASQ).

Dengan ASQ, individu merespon terhadap apa penyebab yang mereka yakini sebagai penyebab munculnya kejadian yang berbeda. Respon mereka dirating berdasarkan persepsi mereka terhadap penyebab (internal vs external, stable vs unstable, global vs specific) (Seligman, 1991). Masalah dengan menggunakan attributional theory dalam memahami optimisme adalah bahwa hal tersebut dapat menjadi sangat kompleks dan bersifat subjektif didasarkan pada self report pengalaman masa lampau (Scheier, Carver, \& Bridges, 2000).

Berdasarkan explanatory style, individu yang percaya pengalaman masa lampaunya positif dan ingatan-ingatan 
negatif adalah di luar kontrol mereka (faktor eksternal), maka dapat dikatakan bahwa mereka memiliki positive explanatory style atau orang yang optimistic. Sedangkan orang yang menyalahkan diri sendiri terhadap kemalangan (faktor internal) dan percaya bahwa mereka tidak akan pernah mendapat sesuatu dikatakan memiliki negative explanatory style atau orang yang pessimistic.

\section{Dispositional Optimism or Direct Belief Model}

Konstruk ini berusaha untuk mempelajari optimisme melalui kepercayaan langsung individu mengenai kejadian masa depan. Pendekatan ini lebih fokus pada kepercayaan optimistik mengenai masa depan, dibanding dengan attributional theory yang berusaha memahami mengapa individu optimis atau pesimis dan bagaimana mereka bisa menjadi seperti itu. Carver dan Scheier (2002) menyatakan bahwa optimisme adalah kecenderungan disposisional individu untuk memiliki ekspektasi positif secara menyeluruh meskipun individu menghadapi kemalangan atau kesulitan dalam kehidupan.

Optimisme merupakan sikap selalu memiliki harapan baik dalam segala hal serta kecenderungan untuk mengharapkan hasil yang menyenangkan. Dengan kata lain optimisme adalah cara berpikir atau paradigma berpikir positif (Carver \& Scheier 1993). Orang yang optimis adalah orang yang memiliki ekspektasi yang baik pada masa depan dalam kehidupannya. Masa depan mencakup tujuan dan harapan-harapan yang baik dan positif mencakup seluruh aspek kehidupannya (Scheier \& Carver, dalam Snyder, 2002). Konsep optimisme dan pesimisme fokus kepada ekspektasi individu terhadap masa depan. Konsep ini memiliki ikatan dengan teori psikologi mengenai motivasi, yang disebut dengan expectancy-value theories.

Beberapa teori juga menyatakan optimisme dan pesimisme memengaruhi perilaku dan emosi seseorang. Expectancy-value theories, yaitu teori yang dimulai dengan ide bahwa perilaku ditujukan untuk pencapaian tujuan (goal) yang diinginkan (Carver \& Scheier, 1998). Goal adalah tindakan, state akhir, atau nilai yang individu lihat sebagai sesuatu yang diinginkan atau tidak diinginkan. Individu akan akan mencoba mencocokkan perilaku, mencocokkan dengan diri mereka sendiri terhadap apa yang mereka lihat yang mereka inginkan, dan mereka akan mencoba untuk menghindari yang tidak mereka inginkan.

Konsep utama lainnya adalah expectancies, yaitu perasaan percaya diri atau ragu-ragu mengenai kemampuan 
meraih tujuan (goal). Hanya dengan kepercayaan diri yang cukup yang individu berusaha mencapai tujuan. Optimisme akan mengarahkan individu untuk selalu memiliki hasil yang baik dan menyenangkan akan masa depannya. Dari prinsip ini, muncul beberapa prediksi mengenai orang yang optimis dan orang yang pesimis. Ketika berhadapan dengan sebuah tantangan, orang yang optimis lebih percaya diri dan persisten, meskipun kemajuannya sulit dan lambat. Orang yang pesimis lebih ragu-ragu dan tidak percaya diri. Perbedaan juga jelas terlihat dalam menghadapi kesengsaraan. Orang yang optimis percaya bahwa kesengsaraan dapat ditangani dengan berhasil. Orang yang pesimis menganggap sebagai bencana. Hal ini dapat mengarahkan pada perbedaan tingkah laku yang berhubungan dengan resiko kesehatan, mengambil pencegahan pada lingkungan yang beresiko, kegigihan dalam mencoba mengatasi ancaman kesehatan. Hal ini juga dapat mengarahkan pada perbedaan respon coping apa yang individu lakukan ketika berhadapan dengan ancaman seperti diagnosis kanker (Carver, Pozo, Harris, Noriega, Scheier, Robinson, Ketcham, Moffat, \&Clark,1993; Stanton \& Snider, 1993). Selain respon perilaku, individu juga mengalami pengalaman emosi pada kejadian dalam kehidupan.

Kesulitan-kesulitan merangsang beberapa perasaan yang merefleksikan baik distres dan tantangan. Keseimbangan antara perasaan-perasaan tersebut berbeda antara orang yang optimis dan pesimis. Karena orang yang optimis mengharapkan good outcome, mereka cenderung mengalami perpaduan emosi yang lebih positif. Karena orang yang pesimis mengharapkan bad outcome, mereka mengalami perasaan-perasaan yang lebih negatif-kecemasan, kesedihan, keputusasaan (Scheier, Carver, \& Bridges, 2001).

Penelitian juga menunjukkan, optimisme memiliki efek moderasi terhadap bagaimana individu menghadapi situasi baru atau sulit. Ketika berhadapan dengan situasi sulit, orang yang optimis akan lebih memiliki reaksi emosi dan harapan yang positif. Mereka berharap akan memperoleh hasil yang positif meskipun hal tersebut sulit. Mereka cenderung menunjukkan sikap percaya diri dan persisten. Orang yang optimis juga cenderung untuk menganggap kesulitan dapat ditangani dengan berhasil dengan suatu cara atau cara lain dan mereka lebih melakukan active dan problem-focused coping strategy dari pada menghindar atau menarik diri (Scheier \& Carver, 1985; Chemers, Hu, \& Garcia, 2001; Scheier, Weintraub, \& Carver,1986). Dari penjelasan dua konsep mengenai optimisme tersebut, dalam penelitian ini, 
konsep optimisme yang digunakan adalah optimisme disposisional, yaitu kecenderungan disposisional individu untuk memiliki ekspektasi positif secara menyeluruh meskipun individu menghadapi kemalangan atau kesulitan dalam kehidupan. Rasa optimis yang muncul dari dalam diri seseorang ditunjukkan dengan adanya sikap selalu memiliki harapan baik dalam segala hal serta kecenderungan untuk mengharapkan hasil yang menyenangkan. Dengan kata lain optimisme adalah cara berpikir atau paradigma berpikir positif (Carver \& Scheier, 1993). Orang yang optimis adalah orang yang memiliki ekspektasi yang baik pada masa depan dalam kehidupannya. Masa depan mencakup tujuan dan harapan-harapan yang baik dan positif mencakup seluruh aspek kehidupannya (Scheier \& Carver, dalam Snyder, 2002). Hal ini sesuai dengan tujuan penelitian untuk melihat optimisme individu terhadap masa depannya daripada menjelaskan penyebab individu menjadi optimis.

Menurut Murdoko dan Prasetya (2003), ciri-ciri orang optimis ada 6 (enam), yaitu :

1. Memiliki visi pribadi. Visi pribadi seseorang akan memiliki cita-cita ideal. Pasalnya, dengan mempunyai visi pribadi seseorang akan memiliki semangat untuk menjalani kehidupan tanpa harus banyak mengeluh ataupun merenungi apa yang telah terjadi dan apa yang akan terjadi nanti. Dengan visi pribadi, individu akan mempunyai tenaga penggerak yang akan membuat kehidupan dinamis dan berusaha untuk mewujudkan keinginankeinginan. Artinya, akan muncul harapan bahwa apa yang akan dilakukan itu membuahkan hasil. Yang lebih penting dengan visi pribadi, individu berpikir jauh ke depan (terutama mengenai tujuan hidup).

2. Bertindak kongkret. Orang yang optimis tidak akan pernah merasa puas jika yang diinginkan cuma sebatas kata-kata. Artinya, betul-betul mempunyai keinginan untuk melakukan suatu tindakan konkret. Mereka secara riil menghadapi tantangan yang mungkin timbul.

3. Berpikir realistis. Seorang optimis akan selalu menggunakan pemikiran yang realistis dan rasional dalam menghadapi persoalan. Jika ingin menanamkan optimisme, maka individu harus membuang jauh-jauh perasaan dan emosi (feeling) yang tidak ada dasarnya. Dengan demikian, segala tindakan apapun perilaku didasarkan pada kemampuan untuk menggunakan akal sehat secara rasional. Dengan 
demikian, apapun yang akan terjadi betul-betul sudah diperhitungkan sebelumnya. Individu yang optimis tingkah lakunya selalu dapat dipertanggungjawabkan. Oleh karena itu, berpikir realistis merupakan sarana untuk tidak mudah diombangambingkan oleh perasaan, karena dengan menggunakan perasaan, maka objektivitas akan berubah menjadi informantivitas.

4. Menjalin hubungan sosial. Kehidupan sosial pada dasarnya dapat dijadikan sebagai salah satu cara mengukur ataupun menilai sejauh mana seseorang mampu menjadikan orang di sekitarnya sebagai partner di dalam menjalani hidup. Orang yang optimis tidak akan merasa terancam oleh kehadiran orang-orang di sekitar. Seorang yang optimis akan menilai bahwa menjalin hubungan sosial akan membuat seseorang merasa dikuatkan, karena merasa punya banyak teman dan sahabat yang akan membantu.

5. Berpikir proaktif. Artinya seseorang harus berani melakukan antisipasi sebelum suatu persoalan muncul, sehingga dituntut memiliki analisis yang tinggi. Karena tanpa adanya analisis mengenai kemungkinan terjadinya sesuatu, maka yang muncul adalah perilaku menunggu, pasif dan baru bertindak saat itu terjadi.

6. Berani melakukan trial and error. Dengan optimisme, kegagalan yang terjadi akan dipahami sebagai hal yang wajar, bahkan tertantang dan menganggap kegagalan sebagai pemicu untuk kembali bangkit. Artinya memiliki kemampuan untuk mencoba dan mencoba lagi tanpa rasa bosan sampai mampu mencapai keberhasilan.

Berdasarkan uraian di atas, dapat ditarik simpulan bahwa ciri-ciri orang optimis adalah memiliki visi pribadi, bertindak kongkret, berpikir realistis, menjalin hubungan sosial, berpikir proaktif dan berani melakukan trial and error. Orang yang mempunyai rasa optimis yang besar akan lebih siap dalam menghadapi masa depannya karena merasa lebih mampu dalam memecahkan permasalahanpermasalahan yang dihadapi dengan ketekunan dan kemampuan berpikir dan sikap tidak mudah menyerah maupun putus asa. Hal tersebut akan memengaruhi pola pikirnya dan sangat berpengaruh sebagai faktor penunjang kesuksesannya.

Whelen, Kim, MacCallum, dan Glaser (1997) melaporkan bahwa optimisme memberikan pengaruh positif terhadap kesehatan, penyesuaian diri setelah operasi kanker, operasi jantung 
koroner, penyesuaian di sekolah dan dapat menurunkan depresi, serta ketergantungan alkohol. Optimisme dalam jangka panjang juga bermanfaat bagi kesejahteraan dan kesehatan fisik dan mental, karena membuat individu lebih menyesuaikan diri dalam kehidupan sosial, pekerjaan, perkawinan, mengurangi depresi dan lebih dapat menikmati kepuasan hidup serta merasa bahagia (Weinstein, 1989; Marshall \& Lang, 1990; Scheier, Carver, \& Bridges, 1994).

Sementara itu, McClelland (1961) menunjukkan bukti bahwa optimisme akan lebih memberikan banyak keuntungan dari pada pesimisme. Keuntungan tersebut antara lain hidup lebih bertahan lama, kesehatan lebih baik, menggunakan waktu lebih bersemangat dan berenergi, berusaha keras mencapai tujuan, lebih berprestasi dalam potensinya, mengerjakan sesuatu menjadi lebih baik, seperti dalam hubungan sosial, pendidikan, pekerjaan dan olah raga. Berdasarkan beberapa penelitian yang telah dilakukan oleh ahliahli di atas dapat dikatakan bahwa optimisme sangat diperlukan oleh individu dalam berbagai bidang kehidupan.

Dalam bidang kesehatan, optimisme mampu meningkatkan kesehatan tubuh, sistem kekebalan, kebiasaan hidup sehat, membuat hidup lebih lama, serta dapat mengurangi depresi, infeksi dalam tubuh dan memengaruhi terhadap penyakit. Dalam bidang sosial, optimisme dapat meningkatkan kepercayaan diri, harga diri, mengurangi sikap pesimis, membuat individu lebih dapat menyesuaikan diri dalam kehidupan sosial serta dapat menikmati kepuasan hidup dan merasa bahagia. Di samping itu, adanya optimisme akan membuat orang lebih sukses di sekolah, pekerjaan, menggunakan waktu lebih bersemangat, lebih berprestasi dalam potensinya.

Salah satu metode untuk meningkatkan optimisme adalah spiritualitas. Kata spiritualitas memiliki akar kata Spirit yang berarti ruh. Dalam Al-Qur'an, term yang merujuk kata spirit antara lain adalah ruh. Dalam bahasa Arab, kata ruhaniyyah bisa diartikan dengan spiritualitas, dan persoalan spiritualitas ada hubungannya dengan potensi ruhani manusia untuk beriman dan komunikai dengan Tuhan. Sebenarnya substansi spiritualitas adalah keimanan kepada Tuhan itu sendiri, sebagai ruh (spirit) dalam kehidupan ini dan Dia-lah sumber energi spiritualitas. Itulah mengapa manusia, baik laki-laki maupun perempuan, memiliki kecenderungan untuk berkomunikasi dan 'berhubungan intim' dengan Tuhan sebagai ekspresi spiritualitasnya (Mustaqim, 2008). 
Spiritualitas berarti hidup berdasarkan atau menurut ruh. Dalam konteks hubungan dengan Yang Transenden, ruh itu adalah Ruh Allah sendiri. Spiritualitas adalah hidup yang didasarkan pada pengaruh dan bimbingan Ruh Allah. Dengan spiritualitas, manusia bermaksud membuat diri dan hidupnya dibentuk sesuai dengan semangat dan cita-cita Allah (Hardjana, 2005).

Spiritualitas dapat dideskripsikan sebagai sebuah proses transformasi dan pertumbuhan atau perkembangan manusia, baik sebagai individu maupun masyarakat, yang bersifat dinamis maupun organik. Spiritualitas adalah sebuah eksplorasi dalam proses menjadi manusia, atau sebuah upaya untuk tumbuh dalam sensitivitas terhadap diri, orang lain, makhluk lain, dan terhadap Tuhan yang berada di dalam dan mengatasi totalitas dunia. Spiritualitas adalah sebuah kekuatan yang bersifat integral, holistik, dan dinamis dalam kehidupan dan berbagai urusan manusia (Rohmaniyah, 2008).

Dimensi spiritual, disebut Frankl sebagai noos, yang mengandung semua sifat khas manusia, seperti keinginan untuk memberi makna, orientasi tujuan, kreativitas, imajinasi, intuisi, keimanan, visi akan menjadi apa, kemampuan untuk mencintai di luar kecintaan yang fisio-psikologis, kemampuan mendengarkan hati nurani di luar kendali superego, selera humor (Zohar \& Marshal, 2000).

Jadi, spiritualitas merupakan sebuah dorongan transenden dari dalam diri untuk lebih mendekatkan diri dan memenuhi kebutuhan transenden yang akan menjadi penunjuk dalam mencapai tujuan hidup dan memperoleh kebahagiaan, keceriaan, intuisi, sukacita, kasih dan kedamaian sehingga individu mampu menghadapi semua persoalan dalam kehidupan serta merupakan kualitas ruhani yang khas pada diri manusia seperti ma'rifah, cinta hasrat mencari kepada Allah, ilmu, ihsan, cinta, ikhlas, taubah, tawakkal, dan jujur.

Robinson (2008), ketika mengoperasionalkan definisi spirituality menyimpulkan tiga aspek pokok, yaitu (1) pengembangan kesadaran dan apresiasi terhadap yang lain (diri sendiri, orang lain, kelompok, lingkungan, dan Tuhan); (2) pengembangan kapasitas dalam merespon orang lain. Hal ini melibatkan aspek praktek, perwujudan spiritualitas dan kontinuitas hubungan dengan yang lainnya; dan (3) pengembangan makna puncak dalam hidup yang dapat membuka kesadaran, apresiasi, dan respon pada yang lain.

Menurut West (2004), inventori orientasi spiritualitas yang dilakukan oleh para terapis religius dan spiritual terdapat 9 aspek, yaitu dimensi transendental 
(transcendental dimension), makna dan tujuan dalam hidup (meaning and purpose in life), misi hidup (mission in life), kesucian hidup (sacredness of life), nilai material yang menantang (challenging material values), altruisme (altruism), adanya idealisme (idealism); kesadaran akan yang tragis (awarenessof the tragic), dan buah dari spiritualitas (fruits of spirituality).

Coyte (2007) menentukan lima aspek dalam spiritualitas,yaitu:

1. Makna (meaning). Makna terkait dengan ontologi keberartian hidup, merasakan situasi hidup, dan memperoleh arah eksistensinya.

2. Nilai (value). Nilai terkait dengan kepercayaan dan standar yang digunakan serta menikmati yang berhubungan dengan kebenaran dan keindahan dari pikiran dan perilaku.

3. Transendental (transcendental). Transenden adalah pengalaman dan penghargaan dari suatu dimensi di luar diri; menyadari keterbatasan diri agar berubah menjadi lebih baik. Transendensi berperan memberikan makna yang mengarahkan tujuan hidup manusia. Nilai-nilai transendental ketuhanan inilah yang akan membimbing manusia menuju nilai-nilai keluhuran universal.

4. Keterhubungan (connecting). Keterhubungan adalah relasi diri dengan orang lain dan Tuhan Zat
Penguasa Alam. Relasi ini didasarkan atas ikatan yang penuh cinta, kesetiaan, komitmen, serta menjaga interaksi komunikasi.

5. Proses Menjadi (becoming). Proses menjadi merupakan rangkaian hidup yang merefleksikan tuntutan dan pengalaman kehidupan yang meliputi perasaan mengetahui "siapa jatidiri" ini dan "bagaimana mengetahuinya". Dalam proses menjadi selalu meyakini bahwa tidak ada apapun di dunia ini tetap kecuali perubahan atau proses menjadi.

Berdasarkan hal tersebut ada 5 aspek spiritualitas, yaitu makna (meaning), nilai (value), transendental (transcendental), keterhubungan (connecting), dan proses menjadi (becoming). Penelitian ini menggunakan aspek-aspek spiritualitas menurut Coyte untuk dikembangkan menjadi sebuah modul intervensi.

Manfaat adanya pengembangan karakter berbasis pada spiritualitas adalah meningkatkan hidup beragama. Dengan menghayati spiritualitas seseorang menjadi orang spiritual, yaitu orang yang mengahayati ruh Allah dalam hidup nyata sehari-hari sesuai dengan panggilan dan peran hidupnya. la menyerap seluruh nilai spiritual dan mengarahkan diri serta hidupnya berdasarkan nilai-nilai spiritualitas dan menciptakan gaya hidup serta perilaku 
menurut nilai-nilai spiritual itu (Hardjana, 2005).

Sebagaimana dikatakan oleh Viktor Frankl (Zohar \& Marshal, 2000), pencarian kita akan makna merupakan motivasi penting dalam hidup kita. Pencarian inilah yang menjadikan kita makhluk spiritual dan ketika kebutuhan makna ini tidak terpenuhi, hidup kita terasa dangkal dan hampa. Ann dan McNicol (Kinasih \& Hadjam, 2011) berpendapat bahwa aspek spiritual memiliki peran meningkatkan kekuatan seseorang mengatasi problem hidup sehari-hari.

Dapat disimpulkan bahwa spiritualitas memiliki manfaat pada seseorang, yaitu menjadikan individu seorang untuk memiliki sikap positif dalam menghadapi setiap kejadian yang datang, tidak kenal putus asa, pantang menyerah, mampu mengontrol sikap dan perilakunya, menghindarkan dari sifat negatif, seperti malas dan tidak percaya diri, serta menjadikan seseorang menjadi orang spiritual yang menyerap seluruh nilai spiritual dan mengarahkan diri serta hidupnya berdasarkan nilai-nilai spiritualitas dan menciptakan gaya hidup serta perilaku menurut nilai-nilai spiritual itu.

Rasa optimis yang muncul dari dalam diri seseorang ditunjukkan dengan adanya sikap selalu memiliki harapan baik dalam segala hal serta kecenderungan untuk mengharapkan hasil yang menyenangkan. Dengan kata lain optimisme adalah cara berpikir atau paradigma berpikir positif, anak yatim piatu yang optimis adalah anak yang memiliki ekspektasi yang baik pada masa depan dalam kehidupannya. Masa depan mencakup tujuan dan harapan-harapan yang baik dan positif mencakup seluruh aspek kehidupannya. Dengan memiliki rasa optimisme terhadap masa depan maka anak yatim piatu diharapkan lebih mampu mengatasi permasalahanpermasalahan dalam kehidupannya baik yang ditimbulkan oleh faktor dari dalam maupun dari luar atau lingkungan.

Spiritualitas memiliki manfaat pada seseorang, yaitu menjadikan individu seorang untuk memiliki sikap positif dalam menghadapi setiap kejadian yang datang, tidak kenal putus asa, pantang menyerah, mampu mengontrol sikap dan perilakunya, menghindarkan dari sifat negatif, seperti malas dan tidak percaya diri, serta menjadikan seseorang menjadi orang spiritual yang menyerap seluruh nilai spiritual dan mengarahkan diri serta hidupnya berdasarkan nilai-nilai spiritualitas dan menciptakan gaya hidup serta perilaku menurut nilai-nilai spiritual itu.

Pengembangan karakter berbasis pada spiritualitas adalah untuk meningkatkan hidup beragama. Dengan 
menghayati spiritualitas maka akan mampu menjadikan seseorang menjadi orang spiritual, yaitu orang yang mengahayati ruh Allah dalam hidup nyata sehari-hari sesuai dengan panggilan dan peran hidupnya. Ia menyerap seluruh nilai spiritual dan mengarahkan diri serta hidupnya berdasarkan nilai-nilai spiritualitas dan

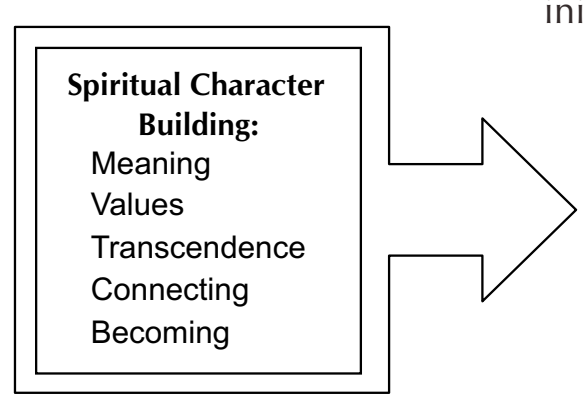

Berdasarkan dinamika psikologis keterkaitan antara spiritual character building dan optimisme terhadap masa depan, maka hipotesis yang diajukan dalam penelitian ini adalah sebagai berikut:

1. Ada perbedaan optimisme terhadap masa depan pada anak yatim piatu di panti asuhan antara yang mendapatkan intervensi berupa Spiritual Character Building dengan anak yatim piatu di panti asuhan yang tidak mendapatkan intervensi berupa Spiritual Character Building. Kelompok yang mendapatkan intervensi Spiritual Character Building memiliki tingkat optimisme yang lebih tinggi dibandingkan menciptakan gaya hidup serta perilaku menurut nilai-nilai spiritual itu. Dengan pengembangan karakter spiritual, maka akan tumbuh nilai-nilai spiritual dalam diri anak yatim piatu dan ini menjadi dasar untuk menumbuhkan dan meningkatkan sikap optimis terhadap masa depan.

Kerangka berpikir dari penelitian ini dapat digambarkan sebagai berikut:

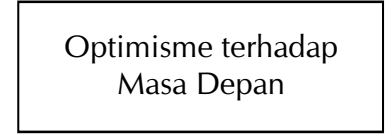

kelompok yang tidak mendapatkan intervensi Spiritual Character Building.

2. Ada perbedaan optimisme terhadap masa depan antara sebelum dan sesudah diberi pelatihan Spiritual Character Building. Ada peningkatan optimisme terhadap masa depan setelah diberi pelatihan Spiritual Character Building.

\section{METODE PENELITIAN}

\section{Subjek Penelitian}

Subjek penelitian ini adalah anak yatim piatu yang tinggal di panti asuhan Aisyiyah Yogyakarta. Karakteristik subjek penelitian ini adalah berusia 12-17 tahun 
dan dipilih dari hasil seleksi skor optimisme terhadap masa depan dengan kategori sedang ke bawah. Seluruh subjek berjumlah 14 orang, yang kemudian dibagi secara random menjadi 2 kelompok, yaitu 7 orang dalam kelompok eksperimen dan 7 orang dalam kelompok kontrol. Kelompok eksperimen diberikan program spiritual character building, sedangkan kelompok kontrol menjadi kelompok waiting list artinya akan diberikan program intervensi yang sama dengan kelompok eksperimen setelah pengambilan data pascates dilakukan.

Subjek diminta untuk menandatangani informed consent sebelum mengikuti prosedur penelitian ini sebagai bukti bahwa subjek benarbenar bersedia mengikuti program kegiatan penelitian ini tanpa ada unsur paksaan. Sebelum menandatangani informed consent, peneliti menjelaskan terlebih dahulu tentang prosedur pelaksanaan kegiatan dan konsekuensi yang akan diterima oleh subjek.

\section{Desain Penelitian}

Penelitian ini menggunakan metode random assignment experiment dengan two group with pre-test and posttest design. Penelitian ini melibatkan dua kelompok, yaitu kelompok eksperimen dan kelompok kontrol, dengan pengambilan data sebelum dan sesudah perlakuan di berikan. Berikut gambar desain eksperimen yang akan dilakukan:

\begin{tabular}{|lllll|}
\hline $\mathrm{R}$ & $\mathrm{KE}$ & $\mathrm{O} 1$ & $\mathrm{X}$ & $\mathrm{O} 2$ \\
$\mathrm{R}$ & $\mathrm{KK}$ & $\mathrm{O} 1$ & - & $\mathrm{O} 2$ \\
\hline
\end{tabular}

Keterangan:

$\mathrm{R}$ : Random Assignment

KE : KelompokEksperimen

KK : Kelompok Kontrol

O1 : Prates (pengukuran optimisme terhadap masa depan sebelum diberi perlakuan)

O2 : Pascates (pengukuran optimisme terhadap masa depan setelah diberi perlakuan)

X : Perlakuan (spiritual character building)

: Tanpa perlakuan

\section{Metode Pengumpulan Data}

Tinggi rendahnya optimisme terhadap masa depan diukur dengan skala optimisme terhadap masa depan berdasarkan teori Murdoko dan Prasetya (2003) yang terdiri atas 6 ciri optimisme terhadap masa depan, yaitu memiliki visi pribadi, bertindak kongkret, berpikir realistis, menjalin hubungan sosial, berpikir proaktif, dan berani melakukan trial and error. Semakin tinggi skor yang diperoleh responden menunjukkan semakin tingginya tingkat optimisme terhadap masa depan, sebaliknya semakin rendah skor yang diperoleh responden menunjukkan semakin 
rendah tingkat optimisme terhadap masa depan.

Aitem-aitem dalam skala optimisme terhadap masa depan menggunakan model skala likert dengan 5 (lima) alternatif respon, yaitu Sangat Tidak Sesuai (STS), Tidak Sesuai (TS), Netral (N), Sesuai (S) dan Sangat Sesuai (SS).Pemberian skor untuk respon terhadap aitem favorable adalah respon Sangat Tidak Sesuai (STS) diberi skor 0, Tidak Sesuai (TS) diberi skor 1, Netral (N) diberi skor 2, Sesuai (S) diberi skor 3, dan Sangat Sesuai (SS) diberi skor 4. Sedangkan untuk respon pada aitem unfavorable maka respon Tidak Sesuai (STS) diberi skor 4, Tidak Sesuai (TS) diberi skor 3, Netral (N) diberi skor 2, Sesuai (S) diberi skor 1, dan Sangat Sesuai (SS) diberi skor 0.

Total skor setiap subjek diperoleh dengan menjumlahkan skor semua aitem dari skala optimisme terhadap masa depan. Semakin tinggi skor yang diperoleh menunjukkan semakin tinggi optimisme terhadap masa depan. Semakin rendah skor yang diperoleh menunjukkan semakin rendah optimisme terhadap masa depan.

Berdasarkan seleksi aitem dengan batasan $r_{i x} \geq 0,3$ dan uji reliabilitas, skala optimisme terhadap masa depan yang terdiri dari 120 aitem sebanyak 70 aitem dinyatakan sahih karena memiliki korelasi aitem dengan aitem total $>0,3$, yaitu bergerak antara 0,302 sampai 0,701 dan terdapat 50 aitem yang gugur karena memiliki korelasi aitem dengan aitem total $<0,3$. Reliabilitas skala dengan menggunakan pendekatan tes satu kali atau pendekatan konsistensi internal menunjukkan koefisien Alpha Cronbach sebesar 0,952.

Spiritual character building adalah program yang disusun dalam bentuk pelatihan yang bertujuan untuk membangun karakter berbasis spiritual. Pelatihan dilaksanakan selama 3 hari dan dibagi dalam 7 sesi, masing-masing hari memiliki durasi selama 8 jam sehingga total pelaksanaan pelatihan ini adalah 24 jam efektif. Materi yang mengacu pada 5 aspek spiritualitas berdasarkan teori Coyte (2007), yaitu makna (meaning), nilai (value), transendental (transcendental), keterhubungan (connecting), dan proses menjadi (becoming).

Selain skala dan modul pelatihan Spiritual character building, penelitian juga menggunakan angket evaluasi yang diberikan kepada subjek setelah selesai membahas seluruh sesi program kegiatan. Angket evaluasi ini berupa pernyataan dan pertanyaan mengenai hal-hal sebagai berikut:

a. Materi yang telah dipahami dari program kegiatan spiritual character building.

b. Materi apa saja yang akan diterapkan 
dalam kehidupan sehari-hari.

c. Tingkat kepuasan terhadap program kegiatan spiritual character building meliputi materi pelatihan, kemampuan pelatih, pelaksanaan pelatihan, dan konsumsi.

d. Tingkat kemanfaatan yang dirasakan terhadap program kegiatan spiritual character building.

e. Saran yang dapat disampaikan untuk perbaikan kegiatan selanjutnya.

\section{Intervensi Penelitian}

Intervensi yang diberikan berupa program kegiatan dalam bentuk pelatihan Spiritual Character Building berdasarkan pada teori spiritualitas yang dikemukakan oleh Coyte (2007), kemudian disusun definisi operasionalnya dalam bentuk modul pelatihan yang dibuat oleh peneliti dibantu oleh mahasiswa.

Komponen materi modul Spiritual Character Building dapat dilihat pada tabel 1 sebagai berikut:

Tabel 1. Materi Modul Spiritual Character Building

\begin{tabular}{cllc}
\hline $\begin{array}{c}\text { Hari } \\
\text { ke - }\end{array}$ & Materi / Aspek & \multicolumn{1}{c}{ Uraian Kegiatan } & Durasi/Jam \\
\hline I & Pengantar & $\begin{array}{l}\text { Perkenalan, prates, dan pohon } \\
\text { harapan }\end{array}$ & 2 \\
& $\begin{array}{l}\text { Peserta mendapatkan materi keber- } \\
\text { Makna } \\
\text { (meaning })\end{array}$ & 3 \\
& $\begin{array}{l}\text { hidup dengan menyikapi kesuksesan } \\
\text { dan kegagalan dan menyusun misi, } \\
\text { arah dan tujuan eksistensi kehidupan }\end{array}$ & \\
& $\begin{array}{l}\text { Materi kepercayaan hidup, acuan } \\
\text { hidup, standar dan norma hidup } \\
\text { serta nilai-nilai puncak yang menjadi } \\
\text { orientasi hidup }\end{array}$ & 3 \\
\hline
\end{tabular}




\begin{tabular}{|c|c|c|c|}
\hline $\begin{array}{l}\text { Hari } \\
\text { ke - }\end{array}$ & Materi / Aspek & Uraian Kegiatan & Durasi/Jam \\
\hline \multirow[t]{3}{*}{ II } & Review & Refleksi dan ice breaking & 2 \\
\hline & $\begin{array}{l}\text { Transendental } \\
\text { (transcendence) }\end{array}$ & $\begin{array}{l}\text { Memunculkan kesadaran akan } \\
\text { keterbatasan diri, penghargaan } \\
\text { di luar diri, pengalaman di luar } \\
\text { diri, termasuk pengalaman puncak }\end{array}$ & 3 \\
\hline & $\begin{array}{l}\text { Keterhubungan } \\
\text { (connecting ) }\end{array}$ & $\begin{array}{l}\text { Menemukan keterhubungan dengan } \\
\text { orang lain melalui cinta, kesetiaan, } \\
\text { komitmen, intensitas komunikasi dan } \\
\text { keterhubungan dengan Tuhan melalui } \\
\text { cinta, kesetiaan, komitmen, intensitas } \\
\text { komunikasi }\end{array}$ & 3 \\
\hline \multirow[t]{4}{*}{ III } & Review & Refleksi dan ice breaking & 2 \\
\hline & $\begin{array}{l}\text { Proses Menjadi } \\
\text { (becoming ) }\end{array}$ & $\begin{array}{l}\text { Reflek si tuntutan hidup menuju lebih } \\
\text { baik dan pengalaman hidup menuju } \\
\text { lebih sempurna }\end{array}$ & 3 \\
\hline & Action Plan & $\begin{array}{l}\text { Membuat rencana aksi Individual } \\
\text { dan kelompok }\end{array}$ & 2 \\
\hline & Penutup & Pascates, evaluasi dan penutupan & 1 \\
\hline
\end{tabular}

Uji coba modul penting dilakukan untuk menguji tingkat validitas isi (content validity) dari materi-materi yang akan disampaikan dalam pelatihan Spiritual Character Building. Proses uji coba modul ini melibatkan subjek sebanyak 5 anak yatim piatu, trainer sebanyak 1 orang dan asisten trainer sebanyak 2 orang. Trainer yang dilibatkan adalah yang sudah berpengalaman atau tersertifikasi dalam bidang spiritualitas dan asisten trainer adalah mahasiswa. Tim trainer dan asisten trainer uji coba modul juga dilibatkan dalam proses pelaksanaan penelitian, yaitu saat pemberian perlakukan pada kelompok eksperimen. Trainer dalam pelatihan ini adalah seorang magister profesi psikologi dan asisten trainer adalah mahasiswa semester 7 yang sudah tutup teori dan memiliki pengalaman pernah menjadi asisten trainer sebelumnya. 


\section{HASIL PENELITIAN}

Pada saat dilakukan uji coba alat ukur dengan melibatkan 45 subjek penelitian selain digunakan untuk melakukan analisis aitem dan uji reliabilitas skala optimisme terhadap masa depan juga digunakan sebagai data pemilihan subjek. Data seleksi subjek diperoleh dari total skor respon subjek penelitian dari 70 aitem yang ada dalam skala optimisme terhadap masa depan.

\section{Deskripsi Subjek}

Setelah diperoleh data skor total dari 45 subjek tersebut, kemudian diseleksi subjek yang memiliki kategori optimisme terhadap masa depan pada tingkat sedang dan rendah saja yang akan dilibatkan dalam pemberian perlakuan. Hal ini sesuai dengan kaedah penelitian eksperimen bahwa subjek yang dapat diberikan perlakuan adalah yang memiliki kondisi atau kategori sedang ke bawah.

Penentuan kategorisasi subjek penelitian menggunakan kategorisasi jenjang yang terbagi dalam 3 (tiga) kategorisasi, yaitu rendah, sedang, dan tinggi. Diketahui bahwa jumlah aitem dalam skala optimisme terhadap masa depan adalah 70 aitem dengan rentang nilai 0 sd 4 sehingga diperoleh nilai minimal 0, nilai maksimal 280, rata-rata (mean) sebesar 140 dan deviasi standar sebesar 46,67. Berdasarkan rumus tersebut dapat diperoleh standar skor prates untuk pembagian kategorisasi subjek adalah sebagai berikut seperti yang dapat dilihat pada tabel 2 di bawah ini:

Tabel 2. Kategorisasi Subjek Penelitian

\begin{tabular}{llcc}
\hline \multicolumn{1}{c}{ Kategori } & \multicolumn{1}{c}{ Skor } & Jumlah & Prosentase \\
\hline Rendah & $X<93,33$ & 0 & $0 \%$ \\
Sedang & $93,33 \leq X<186,67$ & 14 & $31 \%$ \\
Tinggi & $X>186,67$ & 31 & $69 \%$ \\
\hline
\end{tabular}

Penelitian ini menggunakan pendekatan Random Assignment Experiment, yaitu melakukan proses random dalam memilih subjek penelitian. Pemilihan subjek berdasarkan pada data prates dengan menggunakan skala optimisme terhadap masa depan. Subjek yang libatkan dalam penelitian ini adalah yang memiliki skor optimisme terhadap masa depan pada kategori sedang ke bawah. Subjek dengan kategori tersebut sebanyak 14 subjek, 
kemudian dari 14 orang tersebut dibagi secara random dalam 2 kelompok, yaitu 7 orang masuk dalam kelompok eksperimen dan 7 orang masuk dalam kelompok kontrol. Kelompok eksperimen diberikan program spiritual character building selama 3 hari sedangkan kelompok kontrol menjadi kelompok waiting list artinya akan diberikan program intervensi yang sama dengan kelompok eksperimen setelah pengambilan data pascates dilakukan.

Selanjutnya dilakukan pengambilan data pascates kepada 14 subjek sebagai dasar skor optimalisasi terhadap masa depan sebelum perlakuan diberikan, pengambilan data prates dilakukan pada hari Senin, tanggal 10 September di Panti Asuhan Aisyiyah Yogyakarta.

Setelah dilakukan pemberian skor, dapat diketahui data deskriptif skala optimisme terhadap masa depan. Skor minimal 0, skor maksimal 280, rerata 140, dan SD 46,67. Deskripsi data skor hipotetik, dan deskripsi kategorisasi optimisme terhadap masa depan pada kelompok eksperimen tersebut dapat dilihat pada tabel 3 berikut ini:

Tabel 4. Kategorisasi Optimisme pada Kelompok Eksperimen

\begin{tabular}{llcc}
\hline \multicolumn{1}{c}{ Kategori } & \multicolumn{1}{c}{ Skor } & Jumlah & Prosentase \\
\hline Rendah & $X<93,33$ & 0 & $14 \%$ \\
Sedang & $93,33 \leq X<186,67$ & 1 & \\
Tinggi & $X>186,67$ & 6 & $86 \%$ \\
Total & & 7 & $100 \%$ \\
\hline
\end{tabular}

Hal ini menunjukkan bahwa setelah diberi perlakuan berupa kegiatan spiritual character building, optimisme terhadap masa depan subjek penelitian terdapat $86 \%$ dalam kategori tinggi dan $14 \%$ dalam kategori sedang, sedangkan $0 \%$ yang memiliki optimisme terhadap masa depan dalam kategori rendah. 
Tabel 4. Data Deskripsi Statistik

\begin{tabular}{llcccc}
\hline \multicolumn{1}{c}{ Subjek } & Skor & Min & Max & Mean & $\begin{array}{l}\text { Standard } \\
\text { Deviation }\end{array}$ \\
\hline $\begin{array}{l}\text { Kelompok } \\
\text { Eksperimen }\end{array}$ & Prates & 123 & 184 & 156,57 & 23,529 \\
& Pascates & 186 & 242 & 210,57 & 18,146 \\
& Gain & 19 & 81 & 54,00 & 19,655 \\
& Score & & & & \\
Kelompok & Prates & 133 & 186 & 161,29 & 21,838 \\
Kontrol & Pascates & 125 & 204 & 167,57 & 27,294 \\
& Gain & -20 & 31 & 6,29 & 16,640 \\
& Score & & & & \\
\hline
\end{tabular}

\section{Hasil Uji Hipotesis}

1. Hasil Mann Whitney U Test dengan menggunakan gain score diperoleh $\mathrm{t}$ $=1,000, \quad p=0,003 \quad(p<0.01)$. Dengan demikian terdapat perbedaan yang signifikan pada optimisme terhadap masa depan antara kelompok eksperimen dan kelompok kontrol. Kelompok eksperimen mempunyai optimisme terhadap masa depan yang lebih tinggi dibandingkan kelompok kontrol dengan rata-rata optimisme terhadap masa depan pada kelompok eksperimen sebesar 54 dan kelompok kontrol sebesar 6,29.

2. Uji Wilcoxon Test dengan data prates dan pascates pada kelompok eksperimen menunjukkan skor $Z=-$
2,366, $p=0,018(p<0.05)$, artinya ada perbedaan optimisme terhadap masa depan antara sebelum dan sesudah mengikuti pelatihan spiritual character building. Optimisme terhadap masa depan sesudah pelatihan lebih tinggi dibandingkan sebelum pelatihan. Hal ini ditunjukkan dengan skor rata-rata pascates adalah sebesar 210,57 sedangkan rata-rata prates adalah sebesar 156,57.

\section{PEMBAHASAN}

Pendekatan pelatihan yang menggunakan metode experiential learning memberikan banyak kesempatan pada peserta pelatihan untuk belajar dari pengalaman. Hal ini didesain 
pada setiap sesi selalu ada role play. Bermain peran atau role play dimaksudkan untuk memberikan kesempatan merasakan secara langsung apa yang dipelajari sehingga individu dapat menarik simpulan dengan tepat mengenai konsep-konsep pembentukan karakter berbasis spiritual yang disampaikan oleh trainer. Hal ini memungkinkan peserta pelatihan mengukur pengalaman yang dimilikinya. Semakin terbentuk karakter spiritual maka semakin tinggi optimisme terhadap masa depan.

Setelah proses role play, peserta training mendapatkan feedback dari trainer maupun dari peserta pelatihan yang lain. Hal ini memberikan semangat pada diri seseorang ketika ia mendapatkan insentif atau reward dari orang lain. Menurut Murdoko dan Prasetya (2003), jika seseorang mendapatkan insentif dari orang lain terhadap keberhasilan yang dilakukannya (competence contingent insentive), maka akan meningkatkan rasa percaya diri dan optimis.

Dengan penjelasan di atas, maka dapat dilihat dinamika pengaruh pelatihan spiritual character building terhadap optimisme terhadap masa depan. Hal ini juga diperkuat dengan hasil wawancara yang menunjukkan bahwa subjek merasa yakin dapat berhasil di masa depannya karena menyadari potensi positif yang dimilikinya yang telah diberikan oleh Tuhan, dan merasakan kehadiran Tuhan dalam setiap rencana yang dilakukannya, ada sikap tawakkal yang muncul bahwa segala sesuatu itu sudah ditentukan oleh Tuhan dan tugas manusia adalah berusaha sekuat potensi yang dimilikinya.

Pelatihan spiritual character building yang diikuti memberikan kesempatan kepada subjek untuk memahami kesuksesan seseorang selain dipengaruhi oleh kemampuan intelektual, juga dipengaruhi oleh kematangan emosi, namun lebih penting lagi adalah kematangan spiritualnya. Spiritualitas memiliki manfaat pada seseorang, yaitu menjadikan individu seorang untuk memiliki sikap positif dalam menghadapi setiap kejadian yang datang, tidak kenal putus asa, pantang menyerah, mampu mengontrol sikap dan perilakunya, menghindarkan dari sifat negatif, seperti malas dan tidak percaya diri, serta menjadikan seseorang menjadi orang spiritual yang menyerap seluruh nilai spiritual dan mengarahkan diri serta hidupnya berdasarkan nilai-nilai spiritualitas dan menciptakan gaya hidup serta perilaku menurut nilai-nilai spiritual itu.

Hal ini sesuai dengan pendapat Zohar dan Marshall (2000) bahwa saat ini pembentukan pengembangan diri memerlukan pendekatan yang holistik, meliputi aspek kecerdasan intelektual, 
kecerdasan emosional dan kecerdasan spiritual. Tanpa ada kecerdasan spiritual maka tidak mungkin seseorang akan dapat menangkap makna kehidupan.

Pengembangan karakter mengajarkan nilai-nilai yang dapat diterima dan dijadikan sebagai landasan perilaku yang baik dan bertanggung jawab. Pengembangan karakter berbasis spiritualitas dimaksudkan untuk meningkatkan hidup beragama, dengan menghayati spiritualitas dapat menjadikan seseorang menjadi orang spiritual, yaitu orang yang mengahayati ruh Allah dalam hidup nyata sehari-hari sesuai dengan panggilan dan peran hidupnya. la menyerap seluruh nilai spiritual dan mengarahkan diri serta hidupnya berdasarkan nilai-nilai spiritualitas dan menciptakan gaya hidup serta perilaku menurut nilai-nilai spiritual itu. Dengan pengembangan karakter spiritual, maka akan tumbuh nilai-nilai spiritual dalam diri anak yatim piatu dan ini menjadi dasar untuk menumbuhkan dan meningkatkan sikap optimis terhadap masa depan.

\section{SIMPULAN DAN SARAN}

\section{Simpulan}

Simpulan dari penelitian ini adalah sebagai berikut:

1. Berdasarkan analisis data yang dilakukan, dapat disimpulkan bahwa pelatihan spiritual character building terbukti efektif untuk meningkatkan optimisme terhadap masa depan pada subjek penelitian. Hal ini tampak dengan adanya perbedaan skor optimisme terhadap masa depan antara kelompok eksperimen dan kelompok kontrol.

2. Ada pengaruh spiritual character building terhadap peningkatan optimisme terhadap masa depan. Hal ini tampak dengan adanya peningkatan skor optimisme terhadap masa depan pada subjek kelompok eksperimen antara sebelum dan sesudah perlakukan diberikan.

3. Sebagian besar subjek penelitian yang mengikuti kegiatan spiritual character building memiliki tingkat optimisme terhadap masa depan pada kategori tinggi.

\section{Saran}

Saran yang dapat diberikan dari hasil penelitian ini adalah sebagai berikut:

1. Subjek Penelitian

Berdasarkan simpulan tersebut dapat disarankan kepada subjek untuk mengadopsi materi-materi yang disampaikan dalam pelatihan spiritual character building dalam kehidupan sehari-hari sebagai usaha untuk meningkatkan optimisme terhadap masa depan.

2. Peneliti Selanjutnya 
Peneliti menyarankan untuk melakukan replikasi penelitian dengan menggunakan modul pelatihan spiritual character building sebagai bahan intervensi terhadap variabel bebas yang lain sehingga modul pelatihan tersebut dapat teruji validitasnya dalam mengubah perilaku seseorang.

3. Pengasuh Panti Asuhan

Bagi pengasuh panti asuhan untuk memberikan berbagai macam kegiatan bagi anak-anak panti dalam rangka mengembangkan potensi diri mereka. Hal ini dapat dilakukan dengan memberikan pembekalan soft skill berupa pelatihan-pelatihan dengan menjalin kerjasama dengan instansi pendidikan atau LSM.

\section{UCAPAN TERIMA KASIH}

Terima kasih kami ucapkan kepada Lembaga Penelitian Universitas Islam Negeri Sunan Kalijaga Yogyakarta (Lemlit UIN Sunan Kalijaga) yang telah memberikan dana penelitian ini dan terima kasih juga kami sampaikan kepada pengurus dan anak-anak di panti asuhan putri Aisyiyah Yogyakarta atas partisipasi dan kerjasamanya dalam penelitian ini.

\section{DAFTAR PUSTAKA}

Carver C, S., \& Scheier M. F. (1993). On the Power of Positive Thinking:
The Benefits of Being Optimistic. American Psychological Society.

Carver, C. S., \& Scheier, M. F. (1998). On the Self Regulation of Behavior. New York: Cambridge University Press.

Carver, C. S., \& Scheier, M. F. (2002). Optimism. In Snyder, C.R.\& Lopez, S.J.(Eds.), Handbook of Positive Psychology (231-243). New York: Oxford University Press.

Carver, C. S., Pozo, C., Harris, S. D., Noriega, V., Scheier, M. F., Robinson, D. S., Ketcham, A. S., Moffat, F. L., \& Clark, K. C. (1993). How coping mediates the effect optimism on distress: A study of women with early stage breast cancer. Journal of Personality and Social Psychology, 65, 375-390.

Chemers, M.M., Hu, LT., \& Garcia, B.F. (2001). Academic Self Efficacy and First Year College Student Performance and Adjustment. Journal of Educational of Psychology, 93 (1), 55-64.

Cohen, A.B.(2002). The Importance of Spirituality In Well-Being For Jews And Christians. Journal of Happiness Studies 3, 287-310, 2002.

Coyte, M.E. (2007). Spirituality, Values and Mental Health, Jewels for the 
Journey. London: Jessica Kingsley Publishers.

Daaleman, T.P \& Frey, B.B. (2004). The Spirituality Index of Well-Being: A New Instrument fo Health Related Quality of Life Research. Annals of Family Medicine, 2, 499-503.

Hardjana, A.M. (2005). Religiositas, Agama dan Spiritualitas. Yogyakarta: Kanisius.

Hurlock, E.B. (2000). Psikologi Perkembangan. Jakarta : Erlangga.

Kinasih, A. S., \& Hadjam, M. N. R. (2011). Pelatihan Mindfulness Berdasar Konsep Kebersyukuran: Sebuah Promosi Intervensi Psikospiritual untuk Meningkatkan Kesejahteraan Psikologis Remaja Difabel Fisik. Malang: UIN Malang Press.

Marshall, G.N., \& Lang, E.L. (1990). Optimism, Self Mastery, and Symptoms of Depression in Woman Professionals. Journal of Personality and Social Psychology, 62, 1067-1074.
McClelland, D.C. (1961). The Achieving Society. New York: The Free Press.

Moreira-Almeida, A., Neto, F.L., Koenig, H.G. (2006). Religiousness and mental health: a review. Rev Bras Psiquiatr, 28, 242-250.

Murdoko, E.W.H. \& Prasetya, G.T. (2003).Climbing to The Top: 20 Cara Kunci Mencapai Puncak Karir. Jakarta: PT. Elex Media Komputindo.

Mustaqim, A. (2008). Spiritualitas Perempuan dalam AlQur'an.Jurnal. Musawa, 6, No. 2.

Robinson, S. (2008). Spirituality, Ethics and Care. London: Jessica Kingsley Publishers.

Rohmaniyah, I. (2008). Meninjau Ulang Wacana Spiritualitas dan Perempuan. Jurnal Musawa, 6 (2), $140-156$. 